\title{
CALD1 Gene
}

National Cancer Institute

\section{Source}

National Cancer Institute. CALD1 Gene. NCI Thesaurus. Code C113324.

This gene is involved in the stabilization of actin filaments. 